\title{
Pengenalan Teater sebagai Bentuk Literasi terhadap Alam bagi Warga Ponggok (Klaten)
}

\author{
Ari Jogaiswara Adipurwawidjana, Lestari Manggong, Mega Subekti \\ Departemen Susastra dan Kajian Budaya Universitas Padjadjaran, Bandung \\ Jalan Raya bandung-Sumedang Km. 21, Jatinangor, Sumedang \\ E-mail : lestari.manggong@unpad.ac.id
}

\begin{abstract}
Abstrak - Kegiatan workshop yang dijabarkan dalam artikel ini adalah pengenalan teater dengan topik tubuh dan relevansinya dengan pemberdayaan air bagi warga Ponggok (Klaten) dan sekitarnya. Workshop ini dilatarbelakangi oleh reaksi atas kebutuhan untuk meliterasikan warga Ponggok demi melestarikan sumber daya alam di desanya. Penyediaan medium bagi warga Desa Ponggok pada khususnya dan peserta festival GLC19 pada umumnya untuk dapat memahami pentingnya air keberlangsungan hidup masyarakat dapat membantu mereka mengalami pemahaman sustainibilitas sumber daya alam Desa Ponggok. Metode yang dilakukan adalah memberikan pengenalan tentang olah tubuh dalam keterkaitannya dengan menghargai keberadaan dan fungsi air dalam kehidupan. Kegiatan dilakukan di satu kali kesempatan, dalam dua tahap: (1) pengenalan tentang teater dan fungsi teater bagi pendidikan karakter dan pengenalan alam sekitar, dan (2) praktek pendekatan teater melalui gerakangerakan olah tubuh dengan memberdayakan air. Hasil yang diperoleh adalah bahwa medium ini menciptakan ruang berkreasi bagi pesertanya untuk penanaman nilai- nilai pemahaman tentang pentingnya keberadaan air melalui pendekatan teater.
\end{abstract}

Kata kunci: teater, tubuh, pemberdayaan air, Ponggok, pendidikan karakter

Abstract - The workshop activity outlined in this article is an introduction to theater with the topic of the body and its relevance to water empowerment for the citizens of Ponggok (Klaten) and surrounding areas. The workshop was motivated by a reaction to the need to titrate Ponggok residents to conserve natural resources in their villages. The provision of a medium for Ponggok Village residents in particular and GLC19 festival participants in general to be able to understand the importance of community survival water can help them experience an understanding of the sustainability of Ponggok Village's natural resources. The method used is to provide an introduction to the body's exercise in relation to respect for the existence and function of water in life. The activity was carried out on one occasion, in two stages: (1) an introduction to theater and theater functions for character education and introduction to the natural surroundings, and (2) the practice of theatrical approach through bodybuilding movements by empowering water. The result obtained is that this medium creates a creative space for participants to instill the values of understanding about the importance of water through theater approach.

Keywords: theater, body, water empowerment, Ponggok, character education

\section{PENDAHULUAN}

Kegiatan workshop ini merupakan bagian dari program Green Literacy Camp 2019 (GLC19) yang diselenggarakan di Desa Ponggok, Klaten. Program GLC 19 digagas oleh Kepala Desa Ponggok, Klaten, Jawa Tengah sebagai reaksi atas kebutuhan untuk meliterasikan warganya demi melestarikan sumber daya alam di desanya. Kebutuhan inilah yang kemudian menjadi alasan utama mengapa workshop ini dilakukan. Melalui workshop, peliterasian tentang sumber daya alam di Desa Ponggok dilakukan melalui pengenalan teater yang utamanya memberi apresiasi terhadap banyaknya umbul di desa tersebut. Masalah utama yang teridentifikasi pada Desa Ponggok, seperti yang diungkapkan oleh Kepala Desa Ponggok (Junaedhi Mulyono), adalah betapa warga desanya membutuhkan percerahan dan peningkatan kapasitas untuk mampu melestarikan sumber daya alam mereka; sebuah kesadaran akan peri kehidupan berkelanjutan yang harus segera menjadi semangat dan gaya hidup warganya. Satu dekade lalu, warga terpaksa harus mengeksploitasi Umbul Ponggok untuk mengangkat warga Ponggok dari jurang kemiskinan dan jeratan rentenir, untuk memastikan agar sumber daya alam penyambung hidup ini tetap lestari untuk anak cucu mereka. Bagi Bopo Joened, demikian Kepala Desa Ponggok ini 
disapa warganya, literasi adalah jembatan yang tepat. Atas dasar inilah maka kegiatan workshop yang berjudul Pengenalan Teater sebagai Bentuk Literasi terhadap Alama bagi Warga Ponggok digagas dan disertakan dalam rangkaian program GLC19.

Teater dipilih dengan tujuan untuk dapat secara langsung melibatkan peserta workshop untuk berinteraksi dengan sumber daya alam utama Desa Ponggok, yaitu air, yang terdapat dalam banyak umbul di sana. Landasan utama pemilihan genre ini adalah karena sejak awal kemunculannya, drama, yang diekspresikan dalam wujud teater dalam pementasan, merupakan wujud seni yang menunjukkan ekspresi dan interaksi nyata dalam panggung yang merepresentasi cara pandang para pelakonnya terhadap suatu isu dalam masyarakat [1, 2]. Sebagai bentuk ekspresi dalam seni pentas [3], teater menjadi relevan digunakan untuk mengekpresikan apresiasi peserta workshop dalam interaksinya dengan air. Muatan politis yang disisipkan dalam kegiatan berteater juga menjadi sebuah pertimbangan dalam pemilihan teater untuk workshop ini. Seperti yang telah dipaparkan oleh [4, $5,6,7]$ misalnya, teater digunakan sebagai medium penyampaian misi maupun kritik tertentu, karena teater juga berfungsi sebagai sebuah cermin yang memperlihatkan gelagat sosial suatu masyarakat. Selain itu, teater juga dipandang sebagai bagian dari wujud keterlibatan sebuah komunitas, seperti yang pernah dijabarkan oleh [8] dan [9]. Solusi yang direncanakan dapat diambil dari workshop ini adalah perubahan cara pandang peserta workshop tentang bagaimana air di Desa Ponggok dapat dipersepsi lebih dari sumber daya utama yang dapat dieksploitasi. Dalam salah satu materi workshop misalnya, peserta diingatkan tentang pentingnya melakukan kegiatan sederhana yang bersifat simbiosis mutualisme dengan air. Untuk dapat memperoleh solusi tersebut, maka metode pelaksanaan workshop banyak mengadaptasi konsep dan fungsi teater bagi pendidikan karakter dan pengenalan alam sekitar. Karena itulah maka kegiatan utama dalam workshop merupakan praktek pendekatan teater melalui gerakan-gerakan olah tubuh dengan memberdayakan air.

Sebagai salah satu mata acara dalam program GLC19, kegiatan workshop diadakan secara mandiri di hari ketiga, Sabtu tanggal 6 Juli 2019. Dengan kegiatan pokok melakukan pelatihan teater dengan topik tubuh dan relevansinya dengan pemberdayaan air bagi peserta festival dan warga sekitar, kegiatan workshop ini kemudian diberi judul: Pengenalan Teater "Tubuhmu Menuliskan Do'a di Atas Air", yang merupakan wujud literasi terhadap alam, khususnya terhadap keberadaan dan fungsi air bagi sebuah komunitas.

\section{METODE PELAKSANAAN KEGIATAN}

Peserta yang dilibatkan dalam workshop ini adalah warga Desa Ponggok dan peserta festival yang berasal dari berbagai daerah. Workshop ini dilaksanakan pada tanggal 6 Juli 2019 di Desa Ponggok, Klaten Jawa Tengah. Kegiatan ini terdiri atas dua tahap: (1) pengenalan tentang teater dan fungsi teater bagi pendidikan karakter dan pengenalan alam sekitar, dan (2) praktek pendekatan teater melalui gerakan-gerakan olah tubuh dengan memberdayakan air. Untuk tahap 1, materi pelatihan yang diberikan adalah berupa uraian umum tentang definisi dan fungsi drama dan teater merujuk pada definisi drama dan teater yang dikemukakan oleh $[1,2,4,10]$. Untuk tahap 1, materi pelatihan yang dipraktikkan merujuk pada konsep teater sebagai bentuk ekspresi dalam seni pentas seperti yang dikemukakan [3], teater sebagai bentuk pengekspresian yang sifatnya politis seperti yang dikemukakan $[5,6,7]$, dan teater sebagai bagian dari wujud keterlibatan sebuah komunitas merujuk pada $[8,9]$.

Tahapan-tahapan ini dirancang dengan tujuan untuk membekali peserta akan pengetahuan dan juga pengalaman tentang bagaimana air dapat diberdayakan ataupun dieksploitasi. Peserta dibebaskan mengeksplorasi kemampuan olah tubuh mereka dalam berinteraksi dengan alam di sekitar mereka, dengan air sebagai objek utama. Materi utama yang dilatihkan dalam workshop adalah pengenalan tentang teater dan fungsi teater bagi pendidikan karakter dan pengenalan alam sekitar.

Dalam pelaksanannya, kegiatan dipandu oleh tim pelaksana kegiatan yang terdiri terdiri atas tiga orang: ketua tim (Dr. Ari J. Adipurwawidjana, M.A.), anggota 1 (Lestari Manggong, M.A.), dan anggota 2 (Mega Subekti, M. Hum.). Tim ini menyampaikan materi yang terbagi atas kegiatan pengantar, kegiatan inti, dan kegiatan penutup. Kegiatan pengantar, dengan Ari J. Adipurwawidjana sebagai pelaksana, berisi penjelasan latar belakang dan tujuan workshop dan uraian umum tentang teater. Kegiatan inti, dengan Ari J. Adipurwawidjana, Lestari Manggong, dan Mega Subekti sebagai pelaksana, berisi tentang pengenalan tentang fungsi teater bagi pendidikan karakter dan pengenalan alam sekitar, dan juga eksplorasi kemampuan olah tubuh dalam berinteraksi dengan alam di sekitar. Pada kegiatan inti tersebut, peserta workshop diberikan uraian tentang fungsi teater bagi pendidikan karakter dan pengenalan alam, diberikan serangkaian latihan yang terdiri atas 6 bagian, serta dibebaskan mengeksplorasi kemampuan olah tubuh dalam berinteraksi dengan alam di sekitar mereka. 


\section{HASIL DAN PEMBAHASAN}

GLC19 adalah festival literasi desa yang diinisiasi demi menyulut semangat belajar dan berkegiatan literasi segenap warga Ponggok dan masyarakat sekitarnya, agar berdaya dalam melestarikan sumber daya alamnya. Festival ini diselenggarakan pada tanggal 4-7 Juli 2019 di desa yang terkenal karena wisata Unggul Ponggoknya, di Kabupaten Klaten, Jawa Tengah. Program ini dimotori oleh BUMDes Tirta Mandiri Ponggok, Reading Volunteer Indonesia, KOTAKU Klaten, Nemolab, dan Fitonsida Solusi Semesta. Selama empat hari tiga malam, sembilan lokasi yang tersebar di segala penjuru desa seluas 77 hektar tersebut akan dimeriahkan oleh 51 orang narasumber yang terdiri dari sastrawan, budayawan, penggiat literasi dan aktivis lingkungan seperti: Ayah Pidi Baiq, Ahmad Tohari, Jokpin, Kang Maman, Muhiddin M. Dahlan, Anton Kurnia, Aan Mansyur, Ganjar Pranowo, Budiman Sujatmiko, Santi Indra Astuti, Eva Y. Nukman, Sekar Chamdi, Saras Dewi, Hamish Daud, dan Ayu Arman. Mereka akan membagi gagasan terbaik mereka untuk berliterasi demi sustainability. Para kontributor ini akan mengisi 50 mata acara, 25 di antaranya berupa kelas-kelas literasi, dan 9 forum dialog terbuka dengan konsep jagongan di Angkringan Dialog yang dibangun khusus oleh panitia untuk mendekatkan warga dengan narasumber. Semua mata acara diharapkan dapat membawa semangat kehidupan berkelanjutan dan upaya bersama untuk menjaga kelestarian sumber daya alam.

Merujuk pada [4], workshop ini ditempatkan dalam konteks teater sebagai medium pembelajaran. Seperti telah dijabarkan di bagian sebelumnya, workshop ini dibagi menjadi tiga rangkaian kegiatan: kegiatan pengantar, kegiatan inti, dan kegiatan penutup. Kegiatan pengantar merupakan tahap pertama dari dua tahapan yang disampaikan di bagian sebelumnya, sedangkan kegiatan inti merupakan tahap yang kedua. Berikut adalah uraiannya:

\section{a. Kegiatan Pengantar}

Kegiatan pengantar ini merupakan tahap pertama dari dua tahapan yang disampaikan di bagian sebelumnya. Workshop diawali dengan pengantar berupa penjelasan tentang kegiatan lokakarya yang akan dilakukan. Setelah itu, peserta diberikan pengenalan tentang teater dan fungsi teater bagi pendidikan karakter dan pengenalan alam sekitar. Peserta dibekali pengetahuan pengantar tentang definisi teater, yang menurut [10] merupakan seni pentas yang mengedepankan unsur dramatis, yang dihadirkan sebagai pengekspresian fisik suatu isu atau masalah di atas panggung. Pembekalan ini dilakukan agar peserta dapat menempatkan diri sebagai bagian dari pengekspresian cara pandang, sikap, dan reaksi mereka terhadap air yang kemudian dijadikan elemen penentu utama dalam pengekspresian mereka. Fungsi teater bagi pendidikan karakter dan pengenalan alam sekitar juga disampaikan dalam bagian ini untuk menempatkan konteks kegiatan workshop. Contoh penerapan teater sebagai medium untuk pendidikan karakter yang dirujuk adalah yang pernah dikonseptualisaikan oleh [9]. Dalam penjabarannya, Kanter menggarisbawahi perlunya mengekspresikan kesedihan pasca peristiwa 9/11 di Amerika, sebagai outlet agar kesedihan tersebut tidak terus menerus tersimpan dan tidak terluapkan. Untuk itu, Kanter melakukan riset dan mengamati jenis-jenis pengekspresian tersebut di sebuah komunitas di Springfield, Missouri, Amerika Serikat. Serangkaian tulisan berupa puisi dan pementasan-pementasan kecil di sekolah-sekolah diamati, dan menunjukkan poin penting, yaitu, komunitas yang dibangun di atas pijakan kerentanan yang dirasakan oleh semua dapat menjadi landasan kuat untuk proses penyembuhan kolektif terhadap kesedihan tersebut. Contoh ini relevan dengan kegiatan workshop yang dilakukan, dalam hal kegiatan performativitas yang digunakan sebagai sebuah tahap pengekspresian dan pencerminan untuk mengenali masalah yang ada, dan kemudian bercermin padanya agar dapat memiliki pandangan yang lebih objektif.

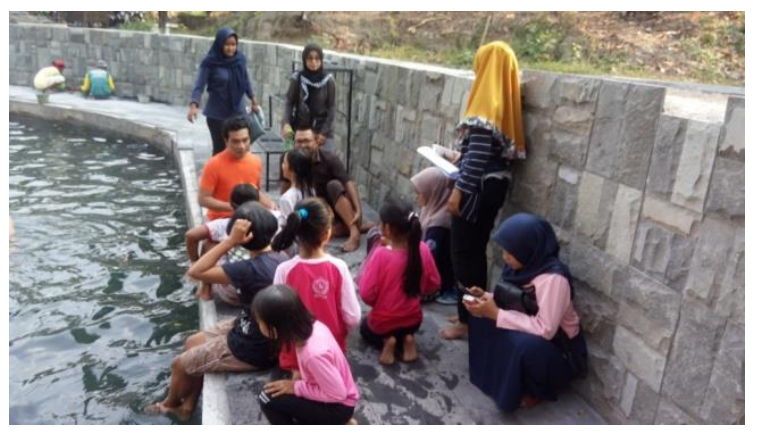

Gambar 1. Ketua Tim, Ari Jogaiswara Adipurwawidjana, Memberikan Pengantar dan Pengenalan Kegiatan

Meskipun materi yang disiapkan untuk pengantar ini cenderung akademis sifatnya, namun kegiatan pengantar disampaikan dengan tidak terlalu teoretis dan filosofis. Hal ini dilakukan agar peserta dapat melaksanakan kegiatannya secara lebih menyenangkan. Yang ditekankan di sini adalah pengalaman ragawi peserta ketika berinteraksi dengan air, dan bagaimana mereka bereaksi terhadapnya.

Setelah pengantar selesai, kegiatan berikutnya adalah kegiatan inti. Seperti yang telah disinggung di awal, materi yang diberikan selama pelaksanaan kegiatan ini terkait dengan persoalan tentang teater yang nantinya diharapkan dapat 
memberikan kebermanfaatan terhadap pengembangan potensi wisata di daerah itu.

\section{b. Kegiatan Inti}

Kegiatan inti ini merupakan tahap kedua dari dua tahapan yang disampaikan di bagian sebelumnya. Materi kegiatan inti terbagi atas enam bagian, yaitu: interaksi dengan alam dan menulis, tubuh, ruang (udara dan gravitasi), gerak dalam ruang, gerak eksploitatif, dan pementasan. Penjabaran rangkaian latihan dalam masing-masing bagian adalah sebagai berikut:

\section{Bagian I: Interaksi dengan Alam dan Menulis}

Dengan mencatat reaksi yang diperlihatkan ketika latihan dilakukan dan juga reaksi yang disampaikan setelah kegiatan workshop selesai, kegiatan ini dilakukan agar peserta dapat berlatih menyadari dan memperhatikan yang ada di luar diri, lalu memadukannya dengan pengalaman internal diri. Kegiatan ini dicapai dengan melakukan latihanlatihan berikut:

\section{Latihan 1}

1. Peserta berdiri tegak, memijakkan kaki ke tanah, dan merasakan tanah di telapak kaki.

2. Peserta memilih daun di pohon atau tanaman yang berjarak minimal 20 meter.

3. Pandangan peserta difokuskan ke daun. Kecuali daun, pandangan lain diburamkan.

4. Peserta menghela dan menghembus nafas, menghela $\mathrm{O} 2$ dan menghembus $\mathrm{CO} 2$ dengan mengucapkan terimakasih kepada daun yang telah memberikan $\mathrm{CO} 2$.

5. Peserta mengulangi aktivitas ini sebanyak lima kali.

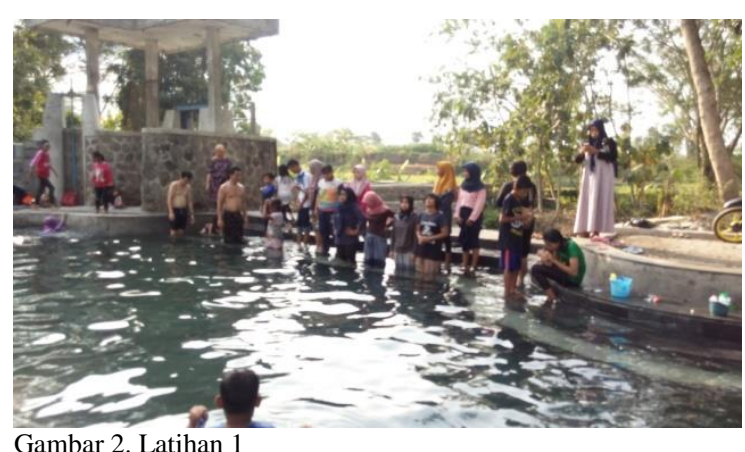

Dalam Latihan 1 ini, peserta diingatkan untuk merasakan keberadaannya secara penuh di atas tanah yang diinjaknya, merasakan tekstur tanah yang ada di bawah kakinya, memfokuskan pandangan pada satu daun, dan melakukan proses memberi dan mengambil dengan daun tersebut. Latihan ini pada intinya mengaksentuasi kemampuan perseptif dan indrawi peserta terhadap apa yang ada di sekelilingnya. Seperti yang telah disampaikan sebalumnya, ukuran capaian kegiatan ini adalah reaksi yang diperlihatkan ketika latihan dilakukan dan juga reaksi yang disampaikan setelah kegiatan workshop selesai. Ketika latihan ini dilaksanakan, tampak peserta perlu waktu untuk membiasakan diri dan berkonsentrasi menempatkan diri dan merasakan keberadaannya dan pada saat yang sama mencoba merekognisi keberadaan benda lain (dalam hal ini daun) di luar mereka. Ini menunjukkan bahwa pada akhirnya peserta dapat mencapai tujuan dari kegiatan ini, meskipun terdapat kesulitan di awal untuk menyesuaikan. Di akhir workshop, peserta secara lisan menyampaikan bahwa tidak mudah melakukan latihan ini yang tampaknya sepele, karena dibutuhkan konsentrasi penuh untuk dapat melakukannya.

Selanjutnya, Latihan 2-5 yang secara detail dijabarkan berikut ini, dilakukan untuk mencapai tujuan yang sama, hanya saja dengan metode yang bervariasi.

\section{Latihan 2}

1. Menghela nafas: Peserta menyalurkan $\mathrm{O} 2$ dari permukaan daun, menyebrang jarak atmosfer, ke lubang hidung, rongga sinus, tenggorokan, bronkia, alveoli, lalu merasakan O2 menyatu dengan darah, bercampur dengan zat besi di hemoglobin, dan membuat darah berwarna merah.

2. Menghembus nafas: Peserta kembali berterimakasih kepada daun, dan membayangkan ke mana $\mathrm{CO} 2$ pergi setelah diserap daun.

3. Peserta mengulangi aktivitas ini sebanyak lima kali.

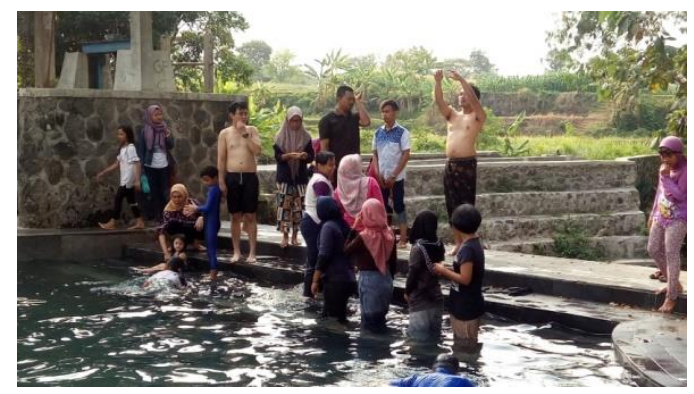

Gambar 3. Latihan 2

\section{Latihan 3}

1. Menghela nafas: Peserta mengambil pemberian daun dan menyebarkan ke semua organ tubuh. Peserta membayangkannya sebagai nyawa mereka, mengingat $\mathrm{O} 2$ merupakan bahan bakar di mitokondria setiap sel tubuh sehingga mereka hidup.

2. Menghembus nafas: Peserta mengembalikan $\mathrm{CO} 2$ dan berterimakasih kepada daun.

3. Peserta mengulangi aktivitas ini sebanyak lima kali. 


\section{Latihan 4}

1. Menghela nafas: Peserta memijakkan kaki, menerima pemberian daun, tangan menangkup ke dalam, bergerak ke arah dada.

2. Menghembus nafas: Peserta membiarkan gravitasi mengambil beban tubuh. Gravitasi tidak bisa dilawan. Peserta berusaha menyentuh tanah yang dipijakkan.

3. Peserta mengulangi aktivitas ini sebanyak lima kali.

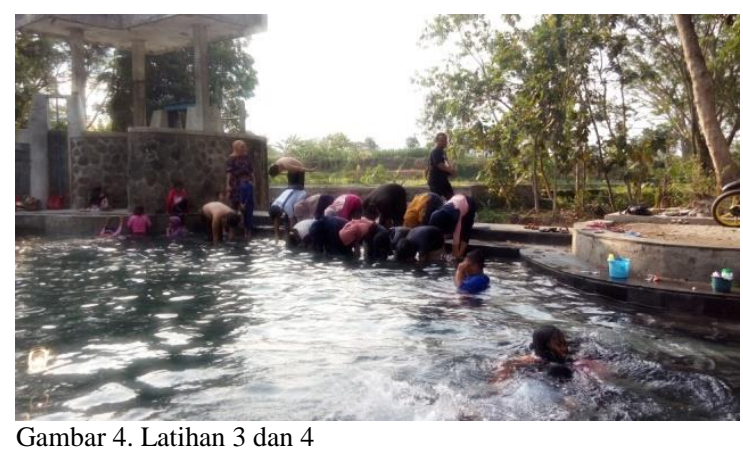

\section{Latihan 5}

1. Peserta membuat kalimat dengan kata "membaca", tetapi tidak boleh menggunakan nama mereka, kata ganti, atau kata-kata abstrak (contoh: indah, segar, hidup, agung, luhur, dan suci.)

2. Peserta menggunakan kata yang menunjukkan pengalaman indrawi. Tidak boleh lebih dari sepuluh kata.

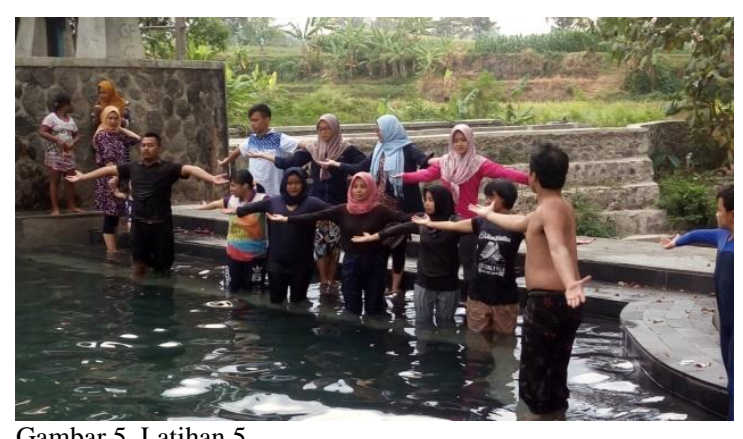

Gambar 5. Latihan 5

Dalam Latihan 2-5, yang pada intinya mengasah interaksi dengan alam dan juga kemampuan mengekspresikan secara tertulis yang diawali dengan kata "membaca", peserta diberikan keleluasaan dan pada saat yang sama, keterbatasan. Keleluasaan yang diberikan adalah kebebasan menemukan cara agar mereka dapat berinteraksi dengan daun yang mereka fokuskan dengan secara detail memvisualisasikannya di benak mereka bagaimana prosesnya berlangsung. Keterbatasan yang diberikan adalah dalam bentuk ketentuan yang harus diikuti ketika mereka menuliskan kalimat yang diawali dengan kata "membaca". Batasan ini justru menjadi tantangan bagi mereka untuk dapat berekspresi dan pada saat yang melakukan pengendalian diri.

\section{Bagian II: Tubuh}

Setelah kegiatan utama mengasah konsentrasi dan pengendalian benak, tahap berikutnya beranjak ke latihan yang lebih fisikal. Kegiatan ini dilakukan agar peserta dapat berlatih mengolah tubuh dengan posisi berdiri, duduk, berbaring di bagian dangkal umbul, sambil menyuarakan kalimat di dalam hati. Aktivitas menyuarakan kalimat di dalam hati inilah yang menjadi realisasi kegiatan menuliskan do'a yang menjadi salah satu inti dari workshop ini. Kegiatan ini terdiri dari tahap-tahap sebagai berikut:

\section{Latihan 1}

1. Peserta berdiri tegak, menghela dan menghembus nafas.

2. Menghela nafas: Peserta menggunakkan nafas untuk meraba tubuh dari dalam.

3. Menghembus nafas: Peserta menceritakan temuannya kepada dunia.

4. Peserta mengulangi aktivitas ini sebanyak sepuluh kali sampai semua organ dalam tergambarkan.

Di Latihan 1 ini peserta memulai dengan membagi pengalaman yang dirasakannya dengan sekitarnya Ketika menghembuskan nafas. Kegiatan menghela dan menghembus nafas dalam hal ini merupakan perwujudan dari kegiatan memberi dan mengambil dan juga membagi dan menerima.

\section{Latihan 2}

Sambil menghela dan menghembus nafas, peserta melakukan aktivitas berikut:

1. Peserta berdiri tegak, tangan di samping, dengan kaki lurus (Posisi 1).

2. Peserta berdiri dengan lutut ditekuk \pm 15 derajat (Posisi 2).

3. Peserta berdiri dengan lutut ditekuk \pm 25 derajat (Posisi 3).

4. Peserta berdiri dengan lutut ditekuk \pm 35 derajat (Posisi 4).

5. Peserta berdiri dengan lutut ditekuk \pm 45 derajat (Posisi 5).

6. Peserta berdiri dengan lutut ditekuk \pm 55 derajat (Posisi 6).

7. Peserta berdiri dengan lutut ditekuk \pm 65 derajat (Posisi 7).

8. Peserta berdiri dengan lutut ditekuk \pm 75 derajat (Posisi 8). 


\section{Latihan 3}

1. Peserta menghela dan menghembus nafas sambil menuturkan kalimat dalam benak dan menelusuri tubuh dari dalam.

2. Peserta menghela dan menghembus nafas sambil menuturkan kalimat dalam benak dan menelusuri Posisi 1-8, vertikal.

3. Peserta menghela dan menghembus nafas sambil menuturkan kalimat dalam benak, menelusuri posisi dengan rentan vertikal dan horizontal Posisi 1-5.

4. Peserta menghela dan menghembus nafas sambil menuturkan kalimat dalam benak, menelusuri posisi horizontal (tubuh bagian atas dan tubuh bagian bawah).

5. Peserta menghela dan menghembus nafas, posisi kobra.

6. Peserta merevisi kalimat.



Dalam Latihan 2 dan 3, dengan posisiposisi tertentu (Posisi 1-8), peserta dibiarkan mengalami berbagai kesulitan yang disebabkan oleh posisi-posisi yang harus mereka lakukan. Pada saat yang sama, di tengah kesulitan tersebut, peserta dibiarkan mengalami sendiri bagaimana dengan kesulitan tersebut mereka harus tetap melakukan tugas mereka, yaitu memberi dan mengambil dan juga membagi dan menerima. Dalam bagian-bagian selanjutnya, peserta dibiarkan berinteraksi ke ruang yang lebih luas, dan bermanuver dalam ruang tersebut.

\section{Bagian III: Ruang (Udara dan Gravitasi)}

Di tepi umbul, peserta melakukan aktivitas berikut:

1. Peserta menghela dan menghembus nafas, posisi push-up, berguling ke kanan dan ke kiri.

2. Peserta menghela dan menghembus nafas, posisi padma hingga terdengar $(\mathrm{h} / \mathrm{h} ; \mathrm{s} / \mathrm{z} ; \mathrm{s} / 3$; $\mathrm{x} / \mathrm{r} ; \mathrm{m} ; \mathrm{n} / \mathrm{j})$.

3. Peserta mengulangi nomor 2 dengan gerak estafet.

4. Peserta mengulangi nomor 2 dengan posisi berdiri.

5. Peserta merevisi kalimat.
Bagian ini merupakan kegiatan pemanasan sebelum peserta benar-benar sepenuhnya merendamkan diri ke air dan secara nyata melakukan interaksi dengan air dalam umbul. Kegiatan menghela dan menghembus nafas sekali lagi dilakukan di sini untuk mengasah dan membuat peserta semakin terbiasa melakukan aksi memberi dan menerima, sambil secara indrawi melalui tubuh mereka dengan berbagai posisi yang dilakukan merasakan tekstur tanah ataupun tembok yang ada di sekitar mereka.

Pada bagian selanjutnya, peserta akhirnya merendam diri ke dalam umbul dan mencoba melakukan interaksi dan mengekspresikan do'a untuk sumber daya air yang ada.

\section{Bagian IV: Gerak dalam ruang}

Di dalam umbul, dengan tubuh sebagian terendam, peserta melakukan aktivitas berikut:

\section{Latihan 1}

1. Peserta menghela dan menghembus nafas: menunjukkan telapak tangan.

2. Peserta menghela dan menghembus nafas: memilih satu orang sebagai pusat pandangan.

3. Peserta menghela dan menghembus nafas: memindahkan perhatian dari tangan ke ruang yang berada dalam tangan.

4. Peserta menghela dan menghembus nafas: menurunkan tangan, tetap fokus pada ruang.

5. Peserta menghela dan menghembus nafas: berserah pada ruang.

\section{Latihan 2}

1. Peserta mengusap air sambil bergerak menuju ruang tangan Liyan (daun dan tanah).

2. Peserta mengulangi nomor 1 dengan permukaan air di garis bibir dan telapak tangan mengusap permukaan air atau udara.

3. Nomor 1 dan 2 divariasikan dan estafet ketika berpapasan.

4. Peserta merevisi kalimat.

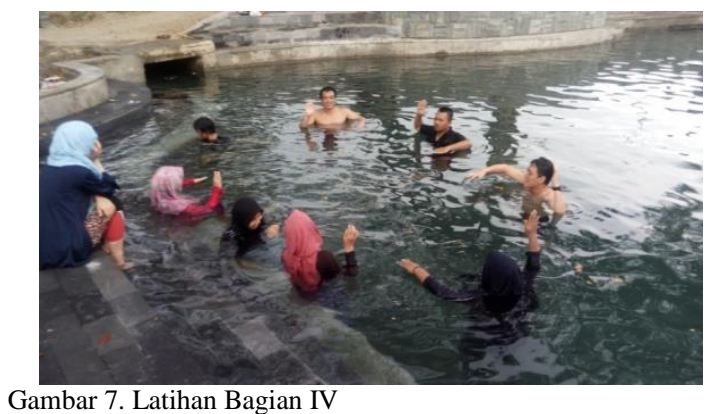

Pada Latihan 1 dan 2 Bagian 4 ini, peserta dibiarkan berinteraksi dengan fokus yang dapat menunjukkan reaksi langsung, yaitu rekan peserta yang lain. Hal ini berbeda dari kegiatan-kegiatan di 
awal yang fokus interaksinya ditujukan kepada daun, sebagai benda yang tidak dapat secara kasat mata dapat dilihat reaksinya. Di dalam umbul, peserta merasakan lingkup air yang merendam mereka, dan di dalamnya bermanuver untuk dapat melakukan interaksi dengan peserta yang lain. Dalam Latihan 2 tampak bahwa peserta dibiarkan melakukan interaksi dengan tingkat rendaman yang berbeda-beda, dengan tujuan untuk mengalami kelimpahan dan pada saat yang sama kesulitan yang dirasakan di dalam air ketika mereka bermanuver.

Pada bagian selanjutnya, bagian 5, peserta difokuskan untuk memeragakan gerak eksploitatif, yang menghilangkan gerakan memberi atau menghembus nafas. Hal ini dilakukan dengan tujuan melihat perbedaan reaksi tubuh peserta Ketika hanya diberdayakan untuk mengeksploitasi atau mengambil sebanyak-banyaknya, tanpa memberi kembali.

\section{Bagian V: Gerak Eksploitatif}

Di dalam umbul, masih dengan tubuh sebagian terendam, peserta melakukan aktivitas berikut:

1. Peserta mengulang Bagian IV dengan fokus pada menghela mengambil, eksploitasi.

2. Peserta memodifikasi Posisi 1-8.

3. Peserta merevisi kalimat.

Tampak pada bagian ini bahwa peserta dibiarkan mengalami pengambilan sebanyakbanyaknya dalam berbagai manuver modifikasi posisi dasar (posisi 1-8) yang dilatihkan sebelumnya. Modifikasi ini mencerminkan betapa peserta dapat secara leluasa menggunakan daya fisiknya dalam aksi mengeksploitasi yang dilakukan.

Bagian selanjutnya merupakan bagian terakhir dalam workshop. Pada bagian akhir ini, peserta ditugaskan untuk mementaskan ekspresi mereka tentang pemberdayaan, penggunaan, apresiasi, maupun pengeksploitasian air dari gerakan-gerakan yang telah dipelajari dalam latihan-latihan sebelumnya. Pementasan ini dilakukan untuk melihat bagaimana peserta bereaksi kolaboratif dan eksploitatif terhadap ruang yang dilingkungi air yang ada dalam umbul yang menjadi panggung pementasan mereka. Pementasan menjadi hal yang penting dalam sebuah pengekspresian fisik yang difokuskan pada suatu isu atau masalah tertentu. Terkait ini, [3] mengemukakan pentingnya menyikapi pementasan sebagai sebuah bentuk sistem penanda dari serangkaian petanda yang ada di sekitar kita. Atas dasar inilah maka kegiatan terakhir berupa pementasan dilakukan dalam workshop ini.

\section{Bagian VI: Pementasan}

Di dalam umbul, peserta melakukan aktivitas berikut:

1. Peserta dibagi menjadi dua kelompok yaitu kelompok kolaboratif dan eksploitatif, lalu merancang gerak.

2. Kelompok kolaboratif dan eksploitatif digabungkan.

3. Peserta mementaskan perpaduan gerakangerakan yang telah dipelajari.
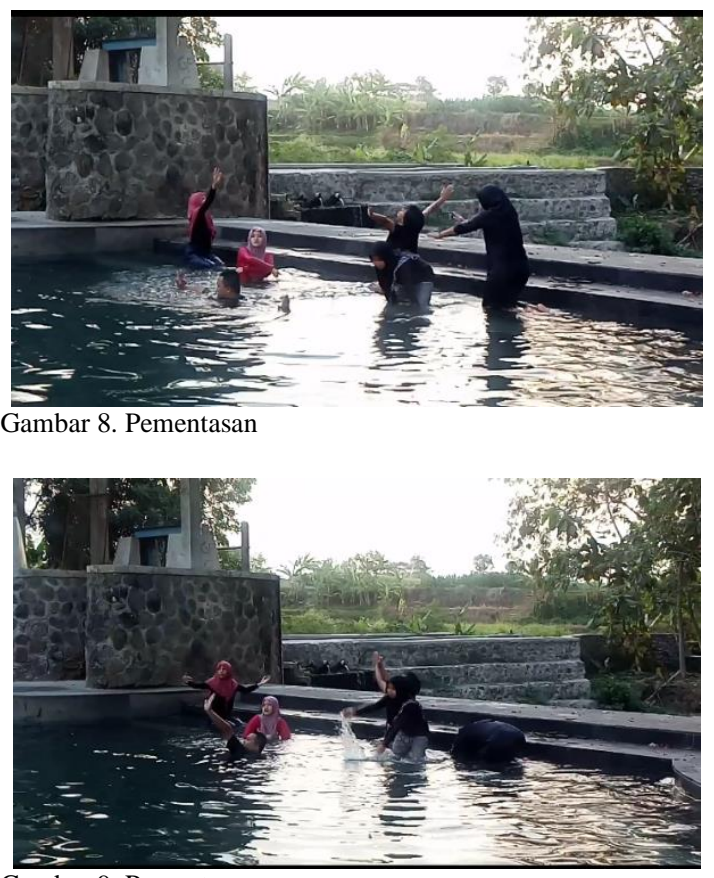

Gambar 9. Pementasan

Pembagian kelompok kolaboratif dan eksploitatif, dalam konteks pemahaman teater yang dikemukakan oleh [5], [6], dan [7], merupakan sebuah cara untuk mengekspresikan hal yang sifatnya politis maupun hal yang sifatnya menunjukkan ideologi tertentu. Kelompok kolaboratif dikondisikan untuk mengekspresikan isu atau masalah pemberdayaan air, sedangkan kelompok ekspoitatif dikondisikan untuk mengekspresikan isu atau masalah pengeksploitasian air.

\section{c. Kegiatan Penutup}

Setelah seluruh latihan selesai dilakukan, kegiatan ditutup dengan penyampaian evaluasi dari peserta. Peserta menyampaikan apa saja dampak dari latihan yang telah dilakukan terhadap cara pandang mereka tentang alam, terutama keberadaan dan fungsi air, serta bagaimana keberadaan air memengaruhi gerakan-gerakan dan cara mereka berinteraksi dan melakukan olah tubuh. Berdasarkan pemaparan dari peserta, didapati bahwa latihan yang dilakukan membuat mereka memiliki cara pandang baru terhadap alam, 
khususnya air. Keberadaan air memengaruhi cara gerak mereka, baik dalam hal membatasi maupun memperkaya gerakan-gerakan mereka. Cara interaksi antar-peserta dan oleh tubuh merekapun dibatasi namun sekaligus juga diperkaya dengan keberadaan air. Setelahnya, ketua tim menutup kegiatan dengan menyampaikan kembali tujuan utama pelatihan, dan meminta peserta untuk menyikapi pelatihan sebagai bentuk pembelajaran atas interaksi dengan alam.

\section{SIMPULAN}

Sebagai kegiatan yang dirancang sebagai pilihan solusi dari masalah yang dikemukakan oleh Bopo Joened di awal, yaitu mengubah pola pikir warganya menjadi ramah lingkungan dan menjalankan peri kehidupan berkelanjutan (sustainability), workshop ini menawarkan sebuah solusi yang bersifat perefleksian diri terhadap alam. Perefleksian diri tersebut diperagakan melalui gerakan-gerakan yang dilakukan dalam rangkaian latihan yang telah dijabarkan di atas. Dari hasil evaluasi yang dilakukan di bagian penutup workshop, tampak bahwa ada tiga hal yang dapat disimpulkan:

1. Peserta dapat secara lebih peka mengenal kontribusi alam dan relasi resiprokal antara manusia dengan alam. Hal ini terlihat dari reaksi peserta yang mengalami fase adaptasi, melakukan banyak pertimbangan ketika secara detail mencoba merasakan interaksi yang dilakukan antara mereka dengan daun di bagian 1 dan 2, dan juga antara sesama mereka di bagian 3-5.

2. Peserta mendapat pembelajaran bahwa relasi yang terjadi antara manusia dengan alamnya adalah relasi memberi, mengambil, meminta, bahkan merampas. Hal ini terlihat dari pengalaman yang mereka sampaikan setelah kegiatan berakhir; bahwa ketika mereka mempraktikkan gerakan-gerakan kolaboratif dan eksploitatif, mereka disadarkan bahwa dalam sebuah interaksi terdapat aksi memberimenerima dan membagi-mengambil. Sebelum mengikuti workshop ini, mereka tidak melihat dan merasakan sendiri secara detail bagaimana aksi-aksi ini direalisasikan.

3. Peserta berhasil mengekspresikan relasi mereka dengan alam melalui perpaduan gerakan yang telah dipelajari dalam latihan. Dan melalui pengekspresian ini, dari hasil evaluasi yang disampaikan di akhir workshop, peserta belajar bahwa relasi mereka dengan alam dan keberlangsungannya melibatkan faktor penentu yang mengendalikan.
Hasil-hasil tersebut diproyeksikan dapat membangun kesadaran dalam diri peserta tentang pentingnya memahami relasi antara manusia dengan alam. Selain itu, pembekalan yang disampaikan dalam workshop juga dapat dijadikan materi pembelajaran untuk diteruskan ke individu atau kelompok atau komunitas lain dengan kepedulian yang serupa.

\section{DAFTAR PUSTAKA}

[1] Banks, R. A. 1985. Drama and Theatre Arts. London: Hodder and Stoughton.

[2] Lennard, J., M. Luckhurst. 2002. The Drama Handbook. Oxford: Oxford University Press.

[3] Aston, E., G. Savona. 1991. Theatre as SignSystem: A Semiotics of Text and Performance. London: Routledge.

[4] Brecht, B. 1964. Theatre for Pleasure or Theatre for Instruction. Brecht on Theatre: The Development of an Aesthetic. John Willet (Ed. and trans.) London: Methuen Drama.

[5] Boal, A. 1979. The Theatre of the Oppressed. New York: Theatre Communications Group.

[6] Gilmore, M. T. 1994. The Literature of the Revolutionary and Early National Periods: The Drama. The Cambridge History of American Literature. Volume One: 15901820. Sacvan Bercovitch (General editor). New York: Cambridge University Press.

[7] Ferreira, M., D. Devine. 2012. Theater of the Oppressed as a Rhizome: Acting for the Rights of Indigenous Peoples Today. Latin American Perspectives, 39(2), 11-26.

[8] Kaluta, J. 2003. The Perfect Stage Crew: The Compleat Technical Guide for High School, College, and Community Theater. New York: Allworth Press.

[9] Kanter, J. 2007. Performing Loss: Rebuilding Community through Theater and Writing, U.S.A.: Southern Illinois University.

[10] Freytag, G. 1900. Technique of the Drama. $3^{\text {rd }}$ Ed. Elias J. MacEwan (Trans.). Chicago: Scott, Foresman \& Co. 